\title{
Observations of tunnel channels in glacial sediments with shallow land-based seismic reflection
}

\author{
A. Pugin, \\ Département de Géologie, 13 Rue des Maraîchers, 1211 Genève 4, Switzerland; \\ Institut für Geophysik, HPP Hönggerberg, 8093 Zürich, Switzerland \\ S. E. Pullan and D. R. Sharpe \\ Terrain Sciences Division, Geological Survey of Canada, 601 Booth Streel, Ollawa, Ontario K1A OE8, Canada
}

\begin{abstract}
A regional hydrogeological study conducted by the Geological Survey of Canada acquired 35 line-km of 12 -fold seismic reflection profiles on or adjacent to the Oak Ridges moraine, north of Toronto, Ontario, Canada. The threedimensional geometry provided by these data aids in understanding the erosional and depositional processes that occurred beneath the Laurentide ice sheet during the late stages of glaciation. The seismic sections indicate large infilled channels in the subsurface which are interpreted as tunnel channels eroded by large, subglacial meltwater discharges. Two seismic profiles from different areas of the moraine show channelcutting events of different ages and different types of infilling.
\end{abstract}

\section{INTRODUCTION}

Much of the population of North America and Europe lives on glacial sediments. The thickness of these deposits can reach $100 \mathrm{~m}$ or more, and some are intensively used for such diverse activities as aggregate extraction, waste disposal and the pumping of drinking water. In order to properly interpret the three-dimensional geometry of glacial deposits, an understanding of glacial processes is necessary. This paper presents interpretations of glacial paleo-environments, on the basis of the spatial distribution of glacial sediments observed in seismic profiles. The geophysical observations presented in this paper were collected by the Geological Survey of Canada (GSC) (Pullan and others, 1994), during a 3 year program to investigate the hydrogeology of the Oak Ridges moraine (ORM) (Fig. 1). This large pro- and subglacial deposit is a major recharge area, with an aquifer system supplying 150000 residents who are dependent on ground-water resources. The ORM also provides aggregate materials and is a recreational area for three million residents of the Greater Toronto Area. The feature covers an area of $1500 \mathrm{~km}^{2}$ and is approximately $160 \mathrm{~km}$ in length, with glaciogenic sediments in places exceeding $200 \mathrm{~m}$ in thickness. One objective of the project was to evaluate the possibility that erosional and infill structures observed north of the ORM, interpreted as tunnel channels (e.g. Barnett, 1990; Brennand and Shaw, 1994), could be traced under the moraine.

\section{Regional geology}

Several investigations of the near-surface nature of the
ORM (e.g. Gravenor, 1957; Karrow, 1984) have concluded that the moraine is a Late Wisconsinan interlobate deposit formed between ice situated over

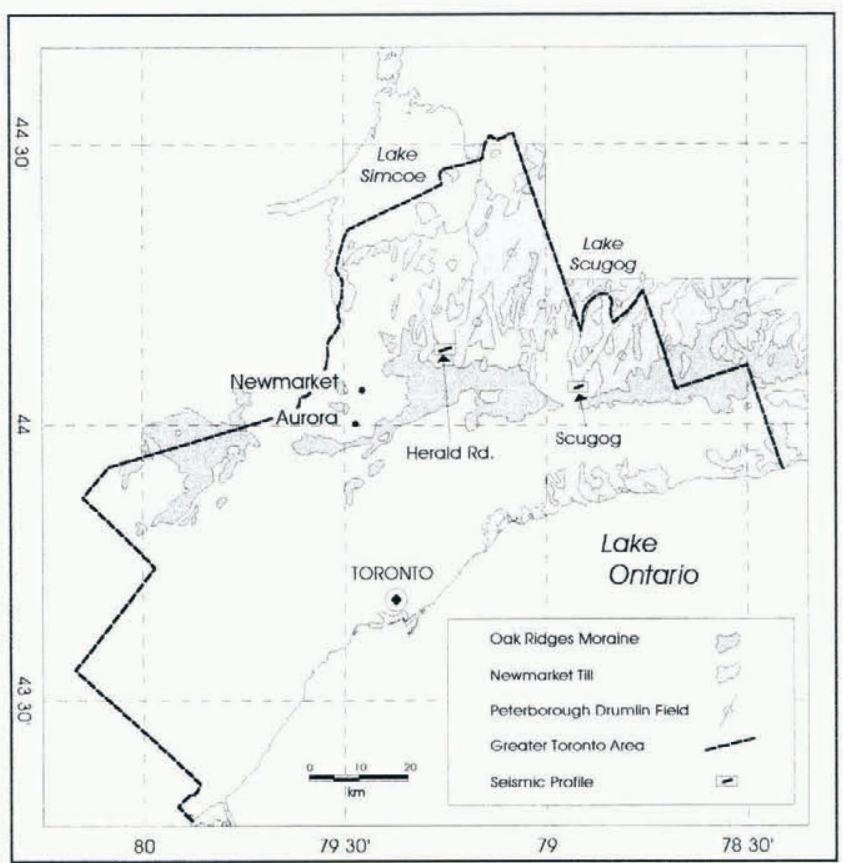

Fig. 1. Location map showing the extent of the Oak Ridges moraine, Newmarket Till and the Peterborough drumlin field near the Greater Toronto Planning Area and the two seismic reflection profiles, Herald Road and Scugog. The white corridor across the Newmarket Till surface indicates the location of tunnel channels. 
Lake Simcoe and Lake Ontario. Glacial and meltwater processes controlled the structure of the ORM. The moraine comprises sand, gravel, silt and clay deposited in a subglacial and proglacial environment, interstratified with diamictons resulting from ice masses to the north and south. A regional till sheet which functions as an aquitard, the Newmarket Till, underlies the moraine (Sharpe and others, 1994). Glacial sediments below the Newmarket are mainly fine-grained, glaciolacustrine sediments. Bedrock consists of Palaeozoic shales and carbonates.

Two mechanisms for the erosion of a network of southsouthwest trending valleys north of the ORM have been proposed:

(1) Meltwater erosion may have produced tunnel channels which deeply eroded Wisconsinan and older sediments (e.g. Shaw, 1983; Sharpe, 1987; Shaw and Sharpe, 1987; Barnett, 1990; Brennand, 1994; Brennand and Shaw, 1994). Episodic meltwater discharge events may have occurred several times during deglaciation.

(2) Glacial erosion associated with ice-streaming within the Laurentide ice sheet as proposed by Boulton (1987), however, has been proposed by Boyce and Eyles (1991) for the same features. In this model, ice overriding the ORM was considered to have preferentially and progressively eroded channels between drumlin ridges following their formation by deformation processes.

\section{Seismic reflection method}

Shallow land-based, multifold seismic reflection techniques (Steeples and Miller, 1991) have been successfully applied to glacial basin analysis in Europe (Pugin and Rossetti, 1992). A simplified seismic profiling technique has also been successfully applied on small glacial basin analysis in Canada (Sharpe and others, 1992). These studies showed that seismic reflection methods could be used to delineate the sub-surface structure of glaciated terrain. The present study is the first in which such seismic surveys have been conducted on this scale; to date, 35 line-km of seismic profiles have been acquired on or adjacent to the ORM.

The shallow seismic data were collected with a 24channel, instantaneous floating-point engineering seismograph, $50 \mathrm{~Hz}$ vertical geophones as receivers, and a 12 gauge, in-hole shotgun source. The shot interval and geophone spacing was $5 \mathrm{~m}$, with a $5 \mathrm{~m}$ off-end offset between source and nearest receiver. The nominal common mid-point (CMP) stack was 12-fold, meaning that 12 traces with a common mid-point between source and receiver positions, but different source-receiver separations, were processed and stacked summed together) to provide a single trace on the processed section. The horizontal spacing between traces on the final section is $2.5 \mathrm{~m}$.

The data processing was performed on an IBMcompatible microcomputer. The usual operations for CMP processing include refraction statics analysis, automatic gain control, band-pass filtering, deconvolution, surgical mute, normal move-out correction, stack and statics on a flat datum plane. Because the near surface of the ORM consists of dry, loose, unconsolidated sediments, which tend to vary laterally in velocity, particular attention was paid to the statics analysis. Innovative arrays of static corrections have resulted in an improvement in the signal-to-noise ratio on the final section by a factor of up to 10 unpublished information from A. Pugin and S. E. Pullan). With an average frequency of $150-250 \mathrm{~Hz}$, the vertical resolution on the final processed seismic sections is estimated to be $1.5-3 \mathrm{~m}$ (one-quarter of the wavelength).

The analysis and interpretation of the profiles presented in this paper are based, in part, on the amplitudes of reflection signals, which provide a measure of the contrast in density and seismic velocity (acoustic impedance) at the reflecting horizon. It is recognized that the true amplitudes have been partly lost through the application of an automatic gain control (AGC, a scaling procedure that operates along the length of each trace to enhance weak signals and suppress large ones). However, this effect has been minimized by only applying an AGC with a window length of $200 \mathrm{~ms}$, so it effectively acts as a trace normalization process. A procedure of this type is necessary to offset the reduction in signal strength as a function of distance travelled. The amplitude information remaining in the data is sufficient to allow qualitative, but not truly quantitative, estimates of acoustic impedance at sub-surface interfaces.

For the interpretation, the velocity determination is based on refraction and stacked velocities obtained during the processing. While lateral variations in velocity are observed, they do not cause significant distortions of the sub-surface structures or the time section, and the time sections only are shown here with an approximate depth conversion noted on the righthand side of the figures. Migration of the data did not significantly affect the final sections, and unmigrated sections are printed here.

\section{SEISMIC PROFILE ANALYSIS}

\section{Herald Road seismic profile}

This seismic reflection profile Figs 1 and 2 crosses a topographic valley, one of a network of large $1-3 \mathrm{~km}$ wide) north-northeast-trending sinuous valleys observed north of the ORM. These valleys are eroded into a regional till sheet, the Newmarket Till, exposed at the surface in adjacent drumlinized uplands Sharpe and others, 1994). These data were acquired to delineate the sub-surface structure of one of these valleys. The profile shows a trough-like structure with several seismic facies distinguished on the basis of amplitude and inner reflectivity. From the top of the section, five seismic facies are recognized and interpreted as follows:

(1) The uppermost facies has very low reflectivity, and contains some reflections which are continuous across the profile. The average seismic velocity in this unit is $1500 \mathrm{~m} \mathrm{~s}^{-1}$. Continuous reflections are interpreted as sand and fine-grained layers deposited as underflows in a glaciolacustrine environment.

(2) The second facies is characterized by a high 
impedance contrast with the uppermost unit; it is present only at the eastern and western sides of the profile and over a downward-curved reflection event at the coordinate (time $50 \mathrm{~ms}$, distance $300 \mathrm{~m}$ ). At the eastern side of the profile, this unit reaches the surface and is observed in outcrop as a compact stony diamicton. It is characterized by a high compressional wave (P-wave) velocity of $2600 \mathrm{~m} \mathrm{~s}^{-1}$. These observations lead to the interpretation of this unit as Newmarket Till.

(3) The top of the central part of the trough infill is not as reflective as the top of facies 2 . The interval velocity calculation for this unit yields an estimated P-wave velocity of $1950 \mathrm{~m} \mathrm{~s}^{-1}\left( \pm 50 \mathrm{~m} \mathrm{~s}^{-1}\right)$. The heterogeneity of this facies is indicated by the presence of numerous downward dome-shaped reflections. This unit is interpreted as stratified sand and gravel, on the basis of its reflection characteristics and seismic velocity. Dome-shaped reflections within this facies suggest the presence of esker deposits.

(4) At either end of the profile, a poorly defined facies is observed below facies 2 (Newmarket Till). Little seismic energy appears to have penetrated the Newmarket Till. Some diffractions are evident in this underlying unit, and it is unconformable with facies 3 (channel fill including the esker deposits). This unit is interpreted as a pre-Late Wisconsinan deposit.
(5) The top of the lowermost seismic facies strongly reflects acoustic energy below the esker and channel infill deposits (facies 3). This suggests that the Newmarket Till (facies 2) is absent in the central part of the trough. Because of the high impedance at the surface of facies 5 and the lack of reflections below this interface, this reflection is interpreted to be the bedrock surface or the top of a lower till. This estimate of bedrock depth agrees with regional-scale estimates from contoured water-well data.

The sharp geometry of the channel and its association with glaciofluvial sediments imply that the channel was formed by erosion of the Newmarket Till and lower drift by meltwater. The channel was then partially infilled with coarse-grained sediments, including some esker deposits. The later deposits indicate subglacial deposition, and hence the channel formed subglacially. Later or perhaps in transition, the channel partially filled with finer-grained glaciolacustrine deposits, likely during ice retreat.

The possible presence of Newmarket Till overlying channel deposits on the east side of the seismic profile (Fig. 2) is attributed to till slumping or moving downslope by a creep mechanism into the partially filled channel between these two stages of deposition. Downslope creep of till (e.g. Alley, 1991) would imply that it was not well consolidated during deposition or during the channel-forming discharge event. However, Newmarket

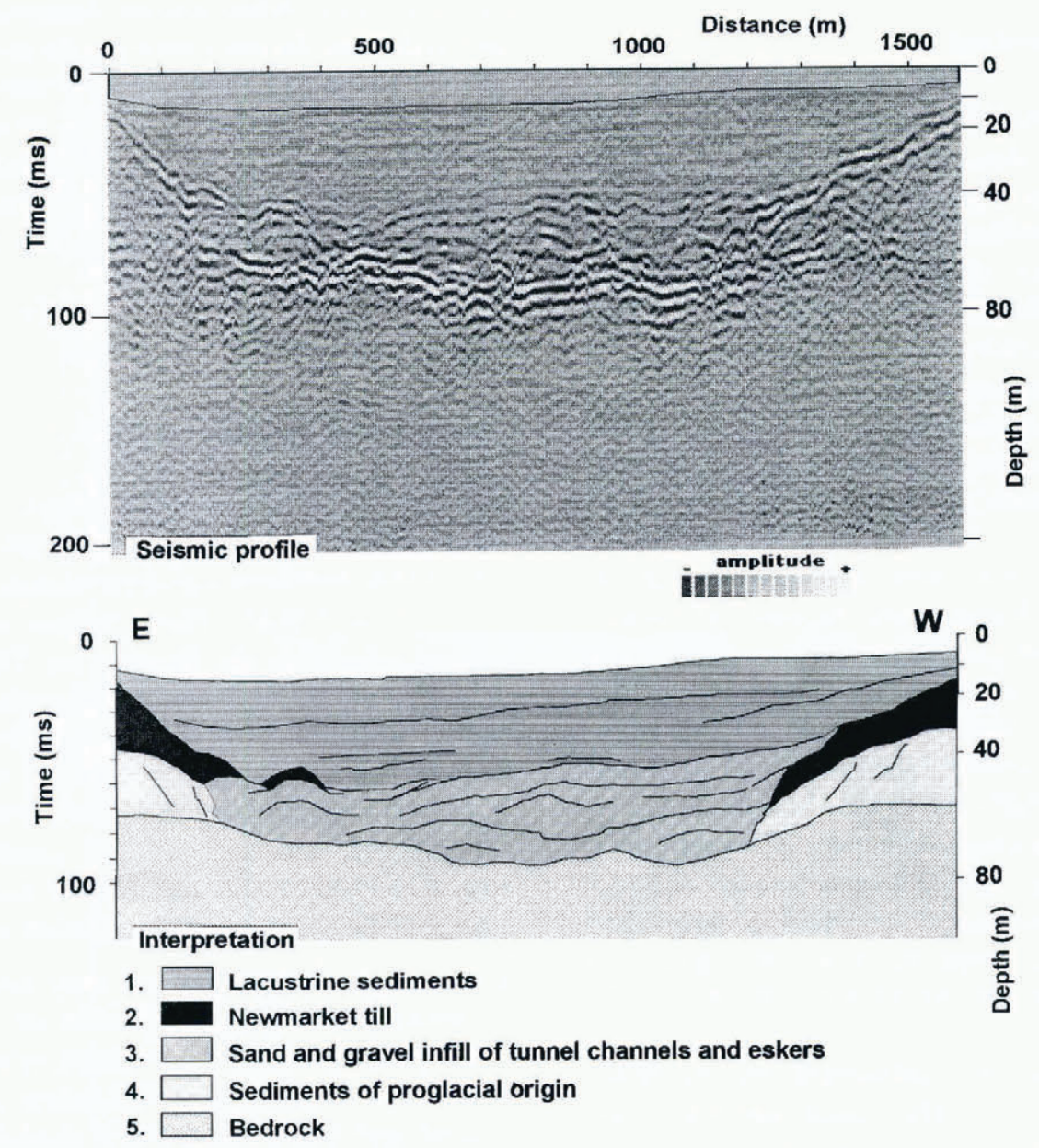

Fig. 2. Herald Road seismic reflection profile and interpretation. This section shows a tunnel channel structure with complete Newmarket Till erosion. 
Till is observed in outcrop to be highly consolidated and is characterized by a very high seismic velocity. Differing seismic velocity and hence consolidation within Newmarket Till may allow one to distinguish primary subglacial deposition from later resedimentation.

Observations such as channel floors rising downflow and inset eskers indicate that tunnel channels formed subglacially during deglaciation of the Laurentide ice sheet Brennand and Sharpe, 1993) and in this area (Brennand, 1994; Brennand and Shaw, 1994). The size and number of channels observed north of the ORM and their steep walls imply channel formation by catastrophic flow (Barnett, 1990) rather than by steady-state flow or sequential development as envisaged elsewhere by Boulton and Hindmarsh (1987). Such subglacial channels may evolve as Nye channels cut in the substrate during the erosion of sub-ice unconsolidated sediments and bedrock (Nye, 1976). When subglacial water erodes up into the ice and forms an ice tunnel, it may then be filled with glaciofluvial or other sediment Röthlisberger, 1972 that produced an esker as flow returned to lowerstage seasonal control. In other seismic profiles GSC open file in preparation) obtained during this study, deep channels have been observed below the ORM. In places channel bottoms may contain a gravel deposit or gravel lag. The sub-surface channel feature observed in the Herald Road seismic profile is more than $1 \mathrm{~km}$ across. The scale and character of the observed channel, and arguments by Röthlisberger (1972) concerning subglacial channel formation, suggest very large meltwater discharges as opposed to formation by ice erosion.

\section{Scugog seismic profile}

This profile (Figs 1 and 3) shows an east-west section across part of the Peterborough drumlin field just south of Lake Scugog. The main feature of this profile is the large dome-like structure in the west-central part of the line. This feature and the underlying stratigraphy on either side are blanketed by a seismic facies that varies between 10 and $15 \mathrm{~m}$ in thickness. Much of the deeper part of this section is characterized by diffraction hyperbolas induced by discontinuous layers or point sources, rather than by any continuous reflections. The diffractions may be related to narrow channels or boulder lags in diamictons. The dome-like structure appears to be underlain by an erosional feature characterized by very steep sides. This is interpreted as an infilled channel approximately $600 \mathrm{~m}$ across and $40 \mathrm{~m}$ deep.

The stratigraphic succession is similar to that described for the Herald Road profile (Fig. 2), except that in this case the Newmarket Till is interpreted to postdate the infilled channel deposits. Hence, we show two ages of channels. Also, the reflection interpreted to be from the bedrock surface is clearly visible along the entire length of the Scugog profile, even through $80 \mathrm{~m}$ of drift, including some $10-15 \mathrm{~m}$ of Newmarket Till. Bedrock in this area is limestone/dolomite, providing an interface with a much higher acoustic impedance than the shale at the Herald Road site.

The geometry of the sediments of the Scugog profile (Fig. 3) suggests that a channel was formed prior to the deposition of the Newmarket Till and to the formation of
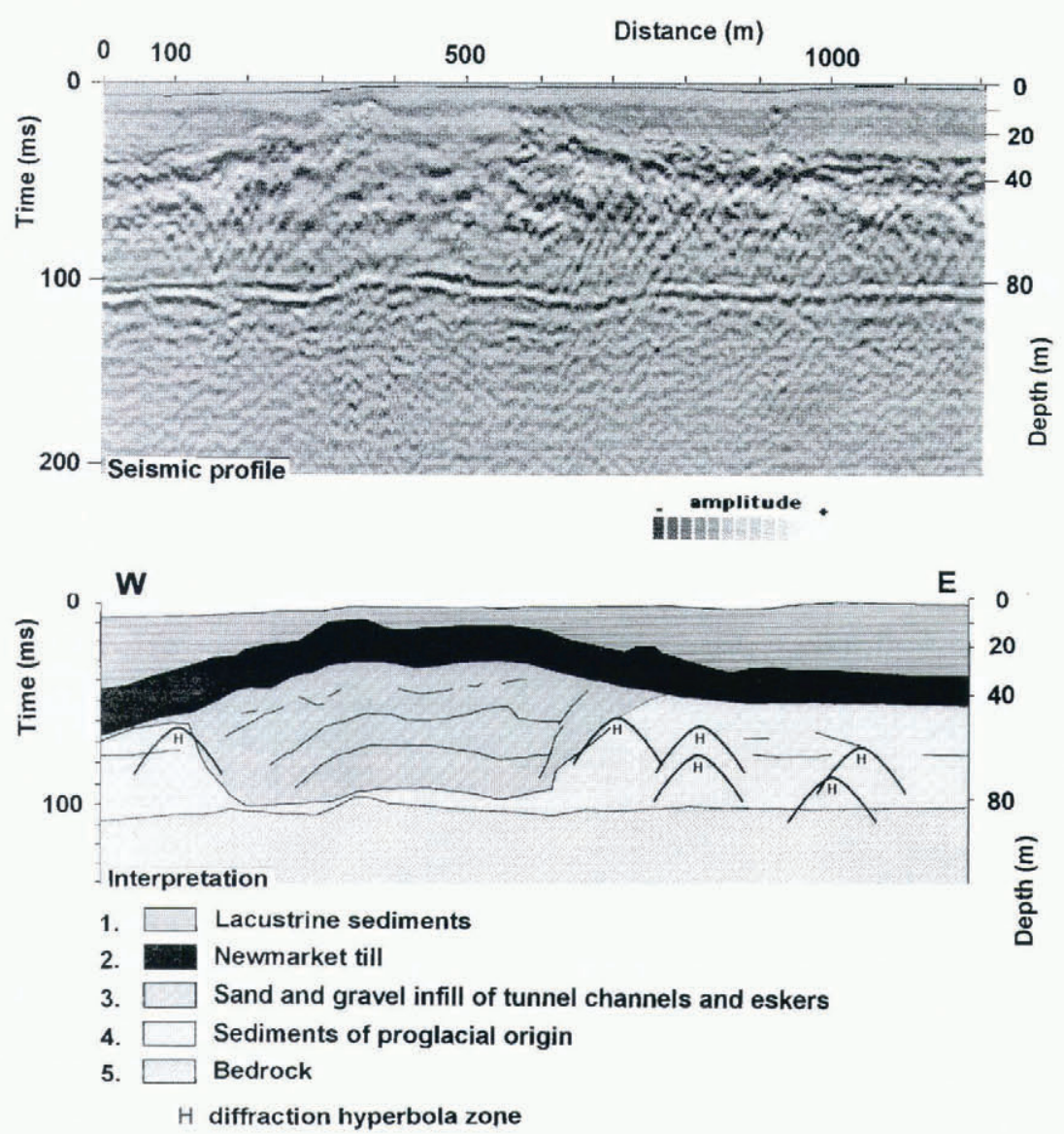

Fig. 3. Scugog seismic reflection profile and interpretation. A tunnel channel is buried below the Newmarket Till. 
the channel interpreted at the Herald Road site. Multiple ages of channels have been observed in other seismic profiles obtained in this study (GSC, open file report in preparation). The steep slopes of the Scugog channel sides imply that it was eroded and infilled in a short period of time (no evidence of lateral creep or slumping). Modern valleys may have steep slopes, but the Scugog profile is adjacent to non-fluvial surface channels filling Lake Scugog.

In contrast to the Herald Road site, the channel erosion did not extend to or into the bedrock surface, and the infill material built up to and above the level of the surrounding sediments. This structure requires ice support during deposition, and is the clearest indication of a subglacial environment of formation. The seismic profile also suggests that the deposition of the Newmarket Till did not involve erosion of the underlying sediments, as had been suggested by Boyce and Eyles (1991) as a mechanism for the formation of the Peterborough drumlin fields.

A similar fill structure was observed in outcrop a few kilometres east of this profile, where a diamicton covers a dome-shaped esker deposit within a drumlin, with no evidence of erosion at the interface between the diamicton and the underlying coarse sediment because they are interbedded (Sharpe, 1987). The conformity of the diamicton with the esker sediment shows a non-erosive relationship with the underlying sediments.

\section{DISGUSSION AND CONGLUSIONS}

Recent literature has suggested that subglacial erosion of glacial sediments and bedrock was at least partly due to periodic high-energy meltwater discharges (e.g. Shaw, 1983; Shaw and Sharpe, 1987; Barnett, 1990). The seismic data shown here delineate the sub-surface structure of large erosional channels in glacial deposits. These observations are consistent with the interpretations of other field evidence in the southern part of the former Laurentide ice sheet (e.g. Shaw and Sharpe, 1987; Barnett, 1990; Brennand and Shaw, 1994) and in the north Brennand and Sharpe, 1993). From the observed distribution and geometry of tunnel channels, these authors suggest that flood events likely occurred during full ice cover. Channel-cutting events appear to have occurred both prior to and after the deposition of a thick regional till (Newmarket Till).

The channel infill deposits shown in the Scugog profile (the earlier event) completely filled the eroded channel and actually built up to higher levels, presumably under ice support. The steep sides of the channel indicate that erosion and infilling were completed in a relatively short period of time. In contrast, the Herald Road profile shows a considerably broader channel $(>1500 \mathrm{~m})$ that was only partly infilled subglacially, and further infilling by ice-marginal sediments. Structures suggesting the existence of esker deposits are recognized in the deeper parts of the Herald Road channel. The upper part of the channel was filled with finer-grained lacustrine sediments at a later stage, perhaps as ice retreated.
Seismic reflection profiling over the Oak Ridges moraine is providing information on the geometry of tunnel channels and their infills. Insights into the paleoglacial environment are gained by studying these sub-surface data. These aid in recognizing and understanding the nature of the glacial deposits and their processes of deposition, and allow for better and more informed decisions or recommendations on the utilization of the resources found in these deposits.

\section{REFERENGES}

Alley, R. B. 1991. Deforming-bed origin for southern Laurentide till sheets? J. Glaciol., $37(125), 67-76$.

Barnett, P. J. 1990. Tunnel vallevs: evidence of catastrophic release of subglacial meltwater, central-southern Ontario, Canada. Geol. Soc. Am. Abstr. Programs, 22 2), 3.

Boulton, G.S. 1987. A theory of drumlin formation by subglacial sediment deformation. In Menzies, J. and J. Rose, eds. Drumlin Symposium. Rotterdam, A. A. Balkema Publishers, 2580.

Boulton, G.S. and R.C.A. Hindmarsh. 1987. Sediment deformation beneath glaciers: rheology and geological consequences. \%. Geophys. Res., 92 B9), 90599082.

Boyce, J. I. and N. Eyles. 1991. Drumlins carved by deforming till streams below the Laurentide ice sheet. Geology, 198), $787-790$.

Brennand, T.A. 1994. Macroforms, large bedforms and rhythmic sedimentary sequences in subglacial eskers, south-central Ontario: implications for esker genesis and meltwater regime. Sediment. Geol., $91(1-4), 955$.

Brennand, T. A. and D. R. Sharpe. 1993. Ice-sheet dynamics and subglacial meltwater regime inferred from form and sedimentology of glaciofluvial systems: Victoria Island. District of Franklin, Northwest Territories. Can. J. Earth Sci., 30 5), $928-944$.

Brennand, T. A. and J. Shaw. 1994. Tunnel channels and associated landforms, south-central Ontario: their implications for ice-sheet hydrology. Can. J. Earth Sci., 31 3), 505-522.

Gravenor, C. P. 1957. Surficial geology of the Lindsay-Peterborough area, Victoria, Peterborough, Durham and Northumberland counties, Ontario. Geol. Surv. Can. Mem. 288.

Karrow, P. F. 1984. Quaternary stratigraphy and history, Great Lakes - St. Lawrence region. Geol. Surv. Can. Pap. 84-10, 138-153.

Nye, J. F. 1976. Water flow in glaciers: jökulhlaups, tunnels and veins. $\mathcal{J}$. Glaciol., 17 76), 181-207.

Pugin, A. and S. Rossetti. 1992. Acquisition of land based high resolution seismic profiles in glacial basins: two case studies in the Alpine foreland of Switzerland. Eclogae Geol. Helv., 85 2), 491-502.

Pullan, S. E. and 6 others. 1994. Shallow geophysics in a hydrogeological investigation of the Oak Ridges Moraine, Ontario. In Bell, R. S. and C. M. Lapper, eds. Proceedings, SAGEEP Meeting, 27 -31 March 1994. Boston, Massachusetts 1. Engelwood, CO, EEGS, 143-161.

Röthlisberger, H. 1972. Water pressure in intra- and subglacial channels. .7. Glaciol., $11(62), 177-203$.

Sharpe, D. R. 1987. The stratified nature of drumlins from Victoria Island and southern Ontario, Canada. In Menzies, J. and J. Rose, eds. Drumlin Symposium. Rotterdam, A.A. Balkema Publishers, 185 214.

Sharpe, D. R., S. E. Pullan and T.A. Warman. 1992. A basin analysis of the Wabigoon area of Lake Agassiz, a Quaternary clay basin in northwestern Ontario. Géogr. Phys. Quat., 46 3), 295-309.

Sharpe, D. R. and 7 others. 1994. 19th Joint Annual Meeting, G.AC/M.AC. Geological Association of Canada and Mineralogical Association of Canada, 16-18 May 1994, Waterloo, Ontario. Gindebook, Field Trip A7: Quaternary geology and hydrogeology of the Oak Ridges moraine area. Waterloo, University of Waterloo.

Shaw, J. 1983. Drumlin formation related to inverted melt-water erosional marks. J. Glaciol., 29 (103), 461-479.

Shaw, J. and D. R. Sharpe. 1987. Drumlin formation by subglacial meltwater erosion. Can. F. Earth Sci., 24 (11), 23162322.

Steeples, D. W. and R.D. Miller. 1991. Seismic reflection methods applied to engineering, environmental and groundwater problems. In Ward, S.H., ed. Geotechnical and environmental geophysics. Vol. 1. Tulsa, OK, Society of Exploration Geophysicists, 1-30. (Investigations in Geophysics 5. 